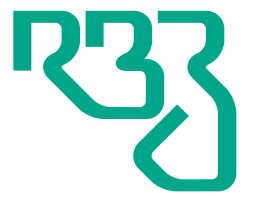

Revista

Brasileira de

Zootecnia

Brazilian Journal of Animal Science

ISSN 1806-9290

www.rbz.org.br

\section{Nutritional plans of digestible phosphorus for gilts from 30 to $100 \mathrm{~kg}$}

\author{
Kelly Cristina Nunes Carvalho ${ }^{1}$ (iD), Charles Kiefer ${ }^{1 *}$ (iD), Karina Márcia \\ Ribeiro de Souza Nascimento $^{1}$ (iD, Tânia Mara Baptista dos Santos ${ }^{2}$ (iD, \\ Marina de Nadai Bonin ${ }^{1}$ (iD, Stephan Alexander da Silva Alencar ${ }^{1}$ iD, Jéssica \\ Lira da Silva ${ }^{1}$, Gabriela Puhl Rodrigues ${ }^{1}$ \\ ${ }^{1}$ Universidade Federal de Mato Grosso do Sul, Faculdade de Medicina Veterinária e \\ Zootecnia, Campo Grande, MS, Brasil. \\ ${ }^{2}$ Universidade Estadual de Mato Grosso do Sul, Departamento de Zootecnia, Aquidauana, \\ MS, Brasil.
}

\begin{abstract}
The objective of this study was to evaluate sequential digestible phosphorus levels for gilts from 30 to $100 \mathrm{~kg}$. Sixty gilts were used, with an initial weight of $29.98 \pm 3.37 \mathrm{~kg}$ and final weight of $100.66 \pm 8.82 \mathrm{~kg}$, distributed in a randomized block design, with five nutritional digestible phosphorus levels: 2.19-1.88-1.68, 2.69-2.38$2.18,3.19-2.88-2.68,3.69-3.38-3.18$, and $4.19-3.88-3.68 \mathrm{~g} \mathrm{~kg}^{-1}$, respectively, for the growth phases 30 to $50 \mathrm{~kg}, 50$ to $70 \mathrm{~kg}$, and 70 to $100 \mathrm{~kg}$, with six replicates and two animals per pen. The nutritional plans did not influence the final weight, days to reach $100 \mathrm{~kg}$, total and daily weight gain, total and daily feed intake, crude protein intake, digestible lysine intake, or metabolizable energy intake. An increase in digestible phosphorus and calcium intake was observed according to the increase in the digestible phosphorus level in the diet. There was a significant effect on feed conversion. No effect of nutritional plans was observed for backfat thickness, muscle depth, loin eye area, lean meat percentage, or carcass bonus index. There was no difference in the production of dry and natural matter or the residue coefficient. The effect of the nutritional digestible phosphorus levels in the contents of total solids and volatile solids was verified. There was a difference in the concentration of total nitrogen and total phosphorus in the manure. The nutritional plan with $3.19-2.88-2.68$ and $3.69-3.38-3.18 \mathrm{~g} \mathrm{~kg}^{-1}$ of digestible phosphorus results in better feed conversion than the basal diet. For a lower excretion of phosphorus in the manure, the recommended nutritional plan is $2.19-1.88-1.68 \mathrm{~g} \mathrm{~kg}^{-1}$ of digestible phosphorus.
\end{abstract}

Keywords: carcass quality, manure, mineral supplementation

\title{
Introduction
}

In pork production, dietary phosphorus supplementation is very important because it is directly involved in metabolism and formation of the bone matrix, along with the levels of calcium and other minerals. Approximately $80 \%$ of phosphorus is found in bones and teeth, mainly in the form of hydroxyapatite, with a w:w ratio of 1:2 with calcium. In addition, it is present in soft tissues, is a nucleic acid constituent, and functions in energy metabolism in the form of ATP, ADP, and AMP, synthesis of carbohydrates, lipids, and proteins, maintenance of acid-base balance, and formation of cell membrane phospholipids (Lehninger et al., 2005). 
Some factors can influence phosphorus requirement. For example, different genetic potentials for deposition of lean tissue in the carcass present different mineral requirements; this is caused by different proportions of soft tissue in relation to bone tissue (Hendricks and Moughan, 1993).

Many studies have shown that the nutritional requirement of pigs varies not only according to the growth phase but also according to genotype, sex, health, ambient temperature, and population density (Saraiva et al., 2009). Even with these differences, it should be considered that excess phosphorus supplementation may affect the animal performance. Furthermore, it may cause an environmental effect because of its excretion into the environment (Saraiva et al., 2009).

Excess phosphorus is excreted by the animal in manure, and together with nitrogen, has a high environmental effect when the waste does not undergo any type of treatment (Genova et al., 2015). Even though most of the soils are deficient in phosphorus and nitrogen, their repeated release into soil causes an accumulation, creating toxic effects on plants and groundwater due to leaching (Carvalho and Zabot, 2012). The most interesting strategy to reduce phosphorus excretion is to improve the nutrient utilization efficiency in animal nutrition by using the appropriate concentrations, according to the requirements of the growing phases (Nieto et al., 2016).

However, there are few studies in literature that evaluated sequential phases and nutritional plans of phosphorus for pigs. Therefore, further studies related to phosphorus levels are necessary, especially those considering the growth phase of animals. In this context, the objective of this study was to evaluate sequential nutritional digestible phosphorus levels for gilts from 30 to $100 \mathrm{~kg}$ in terms of performance, carcass traits, and manure characterization.

\section{Material and Methods}

The research was carried out in Terenos, Mato Grosso do Sul, Brazil (latitude $20^{\circ} 26^{\prime} 32$ "S, longitude $54^{\circ} 51^{\prime} 37^{\prime \prime W}$ ). Research was approved by the Institutional Committee on Animal Use (case number 721/2015).

Sixty gilts (Duroc/Pietran $\times$ Large White/Landrace), with an initial weight of $29.98 \pm 3.37$ and a final weight of $100.66 \pm 8.82 \mathrm{~kg}$, were used in a 73-day trial. The animals were housed in a brick shed containing twenty-five $1.15 \mathrm{~m}$ wide $\times 2.86 \mathrm{~m}$ long pens, equipped with semi-automatic feeders, bite drinkers, and a gutter with water in the bottom of the pen.

Dry bulb, wet bulb, black globe, and relative air humidity (\%) were measured daily at 08.00 and $16.00 \mathrm{~h}$ at six points at the height of the back of animals using a portable digital thermometer, model ITWTG2000. The wet-bulb globe temperature (WBGT) index was calculated using the same equation used by Nieto et al. (2018). The average values of ambient temperature, relative humidity, and WBGT index were $25.59 \pm 3.07^{\circ} \mathrm{C}, 79.98 \pm 13.87 \%$, and $75.30 \pm 4.00$, respectively.

The initial body weight of the animals was considered for the randomized block design, and the animals were allotted in one of five nutritional plans: 2.19-1.88-1.68, 2.69-2.38-2.18, 3.19-2.88-2.68, 3.69-3.38-3.18, and 4.19-3.88-3.68 $\mathrm{g} \mathrm{kg}^{-1}$, for the phases 30 to 50,50 to 70 , and 70 to $100 \mathrm{~kg}$, with six replications and two gilts per experimental unit.

Diets were formulated based on corn and soybean meal, supplemented with minerals and vitamins to meet the nutrient requirements of gilts according to Rostagno et al. (2011). The total phosphorus (TP) concentration of ingredients was evaluated by laboratory tests. The preparation of the experimental diets was based on the digestibility coefficients established by Rostagno et al. (2011) (Table 1).

Experimental diets (Table 2) were supplemented with dicalcium phosphate, considering the reference diet, preparing five diets with different concentrations of digestible phosphorus for each phase (30 to $50 \mathrm{~kg}: 2.19,2.69,3.19,3.69$, and $4.19 \mathrm{~g} \mathrm{~kg}^{-1} ; 50$ to $70 \mathrm{~kg}: 1.88,2.38,2.88,3.38$, and $3.88 \mathrm{~g} \mathrm{~kg}^{-1} ; 70$ to $100 \mathrm{~kg}: 1.68,2.18,2.68,3.18$, and $3.68 \mathrm{~g} \mathrm{~kg}^{-1}$ ). To maintain the constant calcium:digestible phosphorus ratio, diets were supplemented with limestone. 
All feed was provided ad libitum during the experimental period. Feed wastes were collected daily from the floor, weighed weekly, and added to the leftovers at the end of each experimental phase to determine the average daily feed intake.

The weight of the animals was measured at the beginning and end of the experimental period to calculate the daily gain and feed conversion. At the time of the final weight, measurements of the loin eye area $\left(\mathrm{cm}^{2}\right)$, backfat thickness $(\mathrm{mm})$, and muscle depth $(\mathrm{mm})$ were performed by in vivo

Table 1 - Total values of calcium and phosphorus, digestibility coefficient, and digestible phosphorus of the ingredients used in the experimental diets

\begin{tabular}{lcccc}
\hline Ingredient & Calcium $\left(\mathrm{g} \mathrm{kg}^{-1}\right)^{1}$ & Total phosphorus $\left(\mathrm{g} \mathrm{kg}^{-1}\right)^{1}$ & $\mathrm{TPDC}^{2}$ & Digestible phosphorus $\left(\mathrm{g} \mathrm{kg}^{-1}\right)$ \\
\hline Corn & 0.30 & 2.50 & 44.00 & 0.97 \\
Soybean meal, 46\% & 2.40 & 6.40 & 45.70 & 2.60 \\
Dicalcium phosphate & 245.00 & 178.50 & 75.00 & 139.70 \\
Limestone & 377.00 & - & - & - \\
\hline
\end{tabular}

${ }^{1}$ Analyzed values.

${ }^{2}$ True phosphorus digestibility coefficient for pigs (Rostagno et al., 2011).

Table 2 - Composition of basal experimental diets (as fed)

\begin{tabular}{|c|c|c|c|}
\hline \multirow{4}{*}{ Item } & \multicolumn{3}{|c|}{ Phase (kg) } \\
\hline & $30-50$ & $50-70$ & $70-100$ \\
\hline & \multicolumn{3}{|c|}{ Digestible phosphorus $\left(\mathrm{g} \mathrm{kg}^{-1}\right.$ ) } \\
\hline & 2.19 & 1.88 & 1.68 \\
\hline \multicolumn{4}{|l|}{ Ingredient $\left(\mathrm{g} \mathrm{kg}^{-1}\right)$} \\
\hline Corn & 684.27 & 716.99 & 749.07 \\
\hline Soybean meal (46\%) & 268.20 & 240.65 & 212.30 \\
\hline Soybean oil & 9.78 & 7.05 & 4.74 \\
\hline Dicalcium phosphate & 5.32 & 3.35 & 2.19 \\
\hline Limestone & 6.44 & 6.15 & 5.94 \\
\hline Mineral premix & 0.50 & 0.50 & 0.50 \\
\hline Vitamin premix & 1.00 & 1.00 & 1.00 \\
\hline Salt & 4.05 & 3.80 & 3.55 \\
\hline L-lysine $\mathrm{HCl} 78 \%$ & 2.23 & 2.39 & 2.70 \\
\hline DL-methionine $99 \%$ & 0.72 & 0.63 & 0.70 \\
\hline L-threonine $98 \%$ & 0.42 & 0.43 & 0.72 \\
\hline L-tryptophan & - & - & 0.03 \\
\hline Lincomycin & 1.00 & 1.00 & 1.00 \\
\hline Inert (kaolin) & 16.07 & 16.07 & 16.07 \\
\hline \multicolumn{4}{|l|}{ Calculated nutritional composition } \\
\hline Crude protein $\left(\mathrm{g} \mathrm{kg}^{-1}\right)$ & 180.3 & 170.3 & 160.3 \\
\hline Metabolizable energy $\left(\mathrm{kcal} \mathrm{kg}^{-1}\right)$ & 3,255 & 3,252 & 3,251 \\
\hline Digestible lysine $\left(\mathrm{g} \mathrm{kg}^{-1}\right)$ & 9.88 & 9.35 & 8.92 \\
\hline Digestible methionine + cysteine $\left(\mathrm{g} \mathrm{kg}^{-1}\right)$ & 5.83 & 5.52 & 5.35 \\
\hline Digestible threonine $\left(\mathrm{g} \mathrm{kg}^{-1}\right)$ & 6.42 & 6.08 & 5.98 \\
\hline Digestible tryptophan $\left(\mathrm{g} \mathrm{kg}^{-1}\right)$ & 1.87 & 1.73 & 1.61 \\
\hline Sodium $\left(\mathrm{g} \mathrm{kg}^{-1}\right)$ & 1.80 & 1.70 & 1.60 \\
\hline Calcium $\left(\mathrm{g} \mathrm{kg}^{-1}\right)$ & 4.58 & 3.93 & 3.51 \\
\hline Digestible phosphorus $\left(\mathrm{g} \mathrm{kg}^{-1}\right.$ ) & 2.19 & 1.88 & 1.68 \\
\hline Calcium:digestible phosphorus & 2.09:1 & 2.09:1 & 2.09:1 \\
\hline
\end{tabular}

${ }^{1}$ Provided per kg of diet: pantothenic acid, $9.2 \mathrm{mg}$; niacin, $18.0 \mathrm{mg}$; folic acid, $0.5 \mathrm{mg}$; copper, $15.0 \mathrm{mg}$; iron, $0.10 \mathrm{~g}$; zinc, $0.13 \mathrm{~g}$; iodine, $1.0 \mathrm{mg}$; selenium, $0.3 \mathrm{mg}$; manganese, 0.05 g; vitamin A, 5,000 UI; vitamin D3, 1,000 UI; vitamin E, 25.0 UI; vitamin K3, $3.0 \mathrm{mg}$; vitamin B1, $1.5 \mathrm{mg}$; vitamin B2, $4.0 \mathrm{mg}$; vitamin B6, $1.5 \mathrm{mg}$; vitamin B12, $18.0 \mathrm{mg}$; B.H.T (butylated hidroxytoluene) and excipient. 
ultrasonography. The ultrasound device used was the ALOKA 500V, with a $12 \mathrm{~cm}$ acoustic probe with a frequency of 3.5 Mhz. A silicone coupler was used, which accompanies the arching of the ribs allowing for perfect coupling of the transducer with the body of the animal. Soybean oil was used to avoid air between the probe and skin. To perform the ultrasonography, the probe was positioned between the 12 th and 13th ribs. All images were stored in a computer and later analyzed using the program LINCE ${ }^{\circledR}$ (M \& S Consultoria Agropecuária Ltda).

The carcass lean tissue percentage was calculated using the following equation by Guidoni (2000): Lean tissue $(\%)=60-[($ backfat thickness $(\mathrm{mm}) \times 0.58)+($ loin depth $(\mathrm{mm}) \times 0.10)$.

The manure produced was quantified, and analyses were conducted for physical (total [TS] and volatile [VS] solids) and chemical (total nitrogen [TN] and TP) characterization. Within $24 \mathrm{~h}$ after cleaning and drying the water in the bottom of the pen, manure was collected with a shovel, weighed, placed in plastic bags, identified, and stored in a freezer at $-12{ }^{\circ} \mathrm{C}$. They were subsequently placed at room temperature for analysis. Manure production, expressed in kg TS per animal per day, was calculated using the data from manure weight in $\mathrm{kg}$, number of animals housed, number of days, and TS content found in the manure, according to equation: Production of manure $=(\mathrm{kg}$ of manure per animal per day $\times$ TS).

The residue coefficient (RC) was also calculated, which indicates the amount of manure generated per kilogram of the main product. The $\mathrm{RC}$ was obtained considering the total amount of manure produced (dry matter basis) in relation to the weight gain of animals, according to equation: $\mathrm{RC}=$ (Production of manure/weight gain).

Contents of TS and VS were determined according to APHA.AWWA.WPCF (2012). The concentrations of TN and TP were determined according to the methodology described by Silva and Queiroz (2002).

Data obtained on performance, carcass traits, and manure characterization were subjected to analysis of variance, considering the initial weight as a covariate. Differences in study variables were evaluated using Tukey test at a significance level of $5 \%$, and the tests were performed using SAS statistical software (Statistical Analysis System, version 9.1).

The statistical model used to test the effect of treatment and blocks was:

$$
Y_{i j k}=\mu+T_{i}+B_{j}+\varepsilon_{i j k},
$$

in which $Y_{i j k}$ is the quantitative response variable, $\mu$ is the overall mean, $T$ is the effect of $i$-th nutritional plan, $B$ is the effect $j$-th block, and $\varepsilon$ is the random error.

\section{Results}

The nutritional plans did not influence $(\mathrm{P}>0.05)$ the final weight, days to reach $100 \mathrm{~kg}$, total and daily weight gain, total and daily feed intake, crude protein intake, digestible lysine intake, or metabolizable energy intake (Table 3). There was a significant effect $(\mathrm{P}<0.01)$ for feed conversion for the nutritional plans 3.19-2.88-2.68 and 3.69-3.38-3.18, which presented the lowest values for feed conversion. A difference $(\mathrm{P}<0.01)$ was observed for digestible phosphorus and calcium intake, which increased as the phosphorus level in the diet increased.

There was no effect of nutritional plans $(\mathrm{P}>0.05)$ on backfat thickness, muscle depth, loin eye area, lean meat percentage, and carcass bonus index (Table 4$)$. There was no difference $(P>0.05)$ in the production of dry matter, natural matter, or RC, demonstrating that the nutritional digestible phosphorus levels in the diets for gilts from 30 to $100 \mathrm{~kg}$ did not alter manure production (Table 5).

There was an effect $(\mathrm{P}<0.01)$ of the nutritional digestible phosphorus levels on TS and VS contents (Table 6). There was a difference $(\mathrm{P}<0.01)$ in $\mathrm{TN}$ concentration in manure among the nutritional digestible phosphorus levels. The TP concentration also differed $(\mathrm{P}<0.01)$, and the excretion of TP in the manure increased with the digestible phosphorus level in the nutritional plans. 
Table 3 - Performance of gilts between 30 and $100 \mathrm{~kg}$ fed diets containing different nutritional plans of digestible phosphorus

\begin{tabular}{|c|c|c|c|c|c|c|c|}
\hline \multirow{2}{*}{ Variable } & \multicolumn{5}{|c|}{ Nutritional plan } & \multirow{2}{*}{ SEM } & \multirow{2}{*}{ P-value } \\
\hline & 1 & 2 & 3 & 4 & 5 & & \\
\hline IW (kg) & 30.74 & 29.90 & 29.66 & 29.66 & 31.54 & - & - \\
\hline FW (kg) & 94.40 & 103.79 & 101.36 & 99.99 & 104.76 & 2.81 & 0.203 \\
\hline D100 (days) ${ }^{1}$ & 80.00 & 69.33 & 73.00 & 73.67 & 68.25 & 3.48 & 0.079 \\
\hline TWG (kg) & 63.66 & 73.90 & 71.70 & 70.33 & 73.22 & 2.51 & 0.137 \\
\hline DWG (g) & 872 & 1.012 & 982 & 963 & 1.003 & 0.03 & 0.137 \\
\hline ADFI (kg) & 2.29 & 2.57 & 2.32 & 2.29 & 2.57 & 0.10 & 0.690 \\
\hline ATFI (kg) & 167.01 & 187.47 & 169.18 & 167.37 & 187.89 & 7.06 & 0.691 \\
\hline DIDP (g) & $4.26 \mathrm{~d}$ & $6.04 \mathrm{c}$ & $6.62 \mathrm{c}$ & $7.63 b$ & $9.92 \mathrm{a}$ & 0.27 & $<0.001$ \\
\hline DICA (g) & $8.90 \mathrm{~d}$ & $12.62 \mathrm{c}$ & $13.82 \mathrm{c}$ & $16.07 \mathrm{~b}$ & $20.68 a$ & 0.58 & $<0.001$ \\
\hline $\operatorname{DICP}(\mathrm{g})$ & 384.69 & 431.67 & 389.43 & 385.65 & 432.27 & 16.17 & 0.688 \\
\hline DIL (g) & 21.23 & 23.79 & 21.49 & 21.28 & 23.86 & 0.89 & 0.689 \\
\hline DIE (Mcal kg-1) & 7.44 & 8.35 & 7.54 & 7.45 & 8.37 & 0.31 & 0.691 \\
\hline FC & $2.62 \mathrm{a}$ & $2.54 \mathrm{ab}$ & $2.36 \mathrm{~b}$ & $2.38 \mathrm{~b}$ & $2.56 \mathrm{ab}$ & 0.06 & 0.003 \\
\hline
\end{tabular}

Nutritional plans: 1- 2.19-1.88-1.68, 2- 2.69-2.38-2.18, 3- 3.19-2.88-2.68, 4- 3.69-3.38-3.18, 5- 4.19-3.88-3.68 $\mathrm{g} \mathrm{kg}^{-1}$ of digestible phosphorus. IW - initial weight; FW - final weight; D100 - days to reach $100 \mathrm{~kg}$; TWG - total weight gain; DWG - daily weight gain; ADFI - average daily feed intake; ATFI - average total feed intake; DIDP - daily intake of digestible phosphorus; DICA - daily intake of calcium; DICP - daily intake of crude protein; DIL - daily intake of lysine; DIE - daily intake of energy; FC - feed conversion; CV - coefficient of variation.

${ }^{1} \mathrm{D} 100=(100 \mathrm{~kg}-\mathrm{IW}) / \mathrm{DWG}$.

abcd - Means followed by different letters in the row differ $(\mathrm{P}<0.05)$ by Tukey test.

Table 4 - Carcass characteristics of gilts fed diets containing different nutritional plans of digestible phosphorus

\begin{tabular}{lccccccc}
\hline \multirow{2}{*}{ Variable } & \multicolumn{9}{c}{ Nutritional plan } & SEM & P-value \\
\cline { 2 - 6 } & 1 & 2 & 3 & 4 & 5 & & 0.143 \\
\hline BF $(\mathrm{mm})$ & 12.91 & 14.50 & 11.07 & 10.98 & 14.75 & 1.12 & 0.271 \\
LM (mm) & 46.17 & 49.69 & 46.68 & 47.46 & 49.88 & 1.38 & 0.321 \\
LEA $\left(\mathrm{cm}^{2}\right)$ & 38.30 & 41.04 & 39.33 & 42.73 & 44.34 & 2.06 & 0.094 \\
LMP (\%) & 57.13 & 56.56 & 58.25 & 58.37 & 56.49 & 1.40 & 0.237 \\
CBI & 101.03 & 102.48 & 103.06 & 103.48 & 101.51 & 0.80 & \\
\hline
\end{tabular}

Nutritional plans: 1- 2.19-1.88-1.68, 2- 2.69-2.38-2.18, 3- 3.19-2.88-2.68, 4- 3.69-3.38-3.18, 5- 4.19-3.88-3.68 g kg-1 of digestible phosphorus.

$\mathrm{BF}$ - backfat thickness analyzed by ultrasonography; LM- muscle depth analyzed by ultrasonography; LEA - loin eye area analyzed by ultrasonography; LMP - lean meat percentage; CBI - carcass bonus index.

Table 5 -Manure production and residue coefficient of gilts from 30 to $100 \mathrm{~kg}$ fed diets containing different nutritional plans of digestible phosphorus

\begin{tabular}{lccccccc}
\hline & \multicolumn{3}{c}{ Nutritional plan } & SEM & P-value \\
\cline { 2 - 6 } Variable & 1 & 2 & 3 & 4 & 5 & 0.09 \\
MPNM $^{1}$ & 0.872 & 0.905 & 0.676 & 0.748 & 0.895 & 0.671 \\
MPDM $^{1}$ & 0.292 & 0.298 & 0.234 & 0.233 & 0.282 & 0.03 \\
RC $^{2}$ & 0.31 & 0.28 & 0.28 & 0.27 & 0.28 & 0.02 \\
\hline
\end{tabular}

Nutritional plans: 1- 2.19-1.88-1.68, 2- 2.69-2.38-2.18, 3- 3.19-2.88-2.68, 4- 3.69-3.38-3.18, 5- 4.19-3.88-3.68 $\mathrm{g} \mathrm{kg}^{-1}$ of digestible phosphorus. MPNM - manure production in natural matter; MPDM - manure production in dry matter; RC - residue coefficient.

${ }^{1} \mathrm{~kg} \mathrm{day}^{-1}$ animal $^{-1}$

${ }^{2} \mathrm{~kg}$ manure $^{-1} \mathrm{~kg} \mathrm{BW}^{-1 .}$ 
Table 6 - Physicochemical characteristics of manure from gilts from 30 to $100 \mathrm{~kg}$ fed diets containing different nutritional plans of digestible phosphorus

\begin{tabular}{lccccccc}
\hline \multirow{2}{*}{ Variable } & \multicolumn{3}{c}{ Nutritional plan } & SEM & P-value \\
\cline { 2 - 6 } & 1 & 2 & 3 & 4 & 5 & 0.88 \\
TS (\%) & $33.28 \mathrm{ab}$ & $32.71 \mathrm{ab}$ & $35.05 \mathrm{a}$ & $30.81 \mathrm{~b}$ & $30.96 \mathrm{~b}$ & 0.023 \\
VS (\%) & $79.32 \mathrm{c}$ & $80.69 \mathrm{bc}$ & $81.99 \mathrm{ab}$ & $81.95 \mathrm{ab}$ & $83.52 \mathrm{a}$ & 0.54 & $<0.001$ \\
Total N (\%) & $3.25 \mathrm{ab}$ & $3.21 \mathrm{~b}$ & $3.26 \mathrm{ab}$ & $3.44 \mathrm{ab}$ & $3.52 \mathrm{a}$ & 0.07 & 0.003 \\
Total P (\%) & $1.79 \mathrm{~d}$ & $1.85 \mathrm{~cd}$ & $2.06 \mathrm{bc}$ & $2.32 \mathrm{a}$ & $2.24 \mathrm{ab}$ & 0.07 & $<0.001$ \\
\hline
\end{tabular}

Nutritional plans: 1- 2.19-1.88-1.68, 2- 2.69-2.38-2.18, 3- 3.19-2.88-2.68, 4- 3.69-3.38-3.18, 5- 4.19-3.88-3.68 $\mathrm{g} \mathrm{kg}^{-1}$ of digestible phosphorus. TS - total solids; VS - volatile solids.

abcd - Means followed by different letters in the row differ $(\mathrm{P}<0.05)$ by Tukey test.

\section{Discussion}

The mean values of daily feed intake were $2.410 \mathrm{~kg}$ higher than those established by Rostagno et al. (2011), who recommended intake of $2.320 \mathrm{~kg}$, and lower than the $2.508 \mathrm{~kg}$ recommended by Rostagno et al. (2017).

Another study did not observe any effects on feed intake of gilts from 33 to $55 \mathrm{~kg}$ and 88 to $109 \mathrm{~kg}$ (Hastad et al., 2004). Nieto et al. (2018) also did not observe effects on feed intake of barrows from 30 to $100 \mathrm{~kg}$, when evaluating different nutritional plans. Conversely, a significant difference in daily feed intake, considering digestible phosphorus levels for pigs from 9 to $119 \mathrm{~kg}$, was observed in a study conducted by Stahly et al. (2000).

According to Gonzalo et al. (2018), dietary phosphorus deficiency affects feed intake and growth of pigs, being more significant in younger pigs. It can be explained because low phosphorus levels decrease basal metabolism, consequently, decreasing appetite. It can be inferred from the present study that the digestible phosphorus levels did not negatively affect feed intake, considering there was no extreme nutritional deficiency in phosphorus.

In the present study, animals consuming the basal nutritional plan of $2.19-1.88-1.68 \mathrm{~g} \mathrm{~kg}^{-1}$ presented lower feed intake than those on the 4.19-3.88-3.68 $\mathrm{g} \mathrm{kg}^{-1}$ plan; however, it was still possible to meet the requirements of animals with a lower digestible phosphorus supply. Because of the difference in the digestible phosphorus intake, animals fed the nutritional plan $2.19-1.88-1.68 \mathrm{~g} \mathrm{~kg}^{-1}$ consumed $30 \%$ less digestible phosphorus compared with the animals on nutritional plan $3.19-2.88-2.68 \mathrm{~g} \mathrm{~kg}^{-1}$, without detriment to performance. Because daily feed intake did not increase, it could be inferred that the response was linked to the increase in phosphorus levels in the diets. Calcium intake increased with increasing digestible phosphorus levels in the diet, and the effect on calcium was related to diets, which was formulated to maintain the recommended 2:1 of calcium:phosphorus ratio.

However, the values presented in the present study are below the recommendations established by Rostagno et al. (2011), which were 3.19, 2.88, and $2.68 \mathrm{~g} \mathrm{~kg}^{-1}$ with a daily intake of 5.73, 6.68, and $7.27 \mathrm{~g}$ digestible phosphorus for gilts with high potential for deposition of muscle tissue in the growth phases of 30 to 50,50 to 70 , and 70 to $100 \mathrm{~kg}$, respectively. These values were also lower than those of the most recent Brazilian table, which recommended 3.49,3.04, and $2.74 \mathrm{~g} \mathrm{~kg}^{-1}$ and a daily intake of $5.44,6.35$, and $6.89 \mathrm{~g}$ digestible phosphorus for sows with high potential for deposition of muscle tissue in the growth phases of 30 to 50, 50 to 70, and 70 to $100 \mathrm{~kg}$, respectively (Rostagno et al., 2017).

According to NRC (2012), the recommended digestible phosphorus for swine is $3.30 \mathrm{~g} \mathrm{~kg}^{-1}$ for 25 to $45 \mathrm{~kg}, 3.30 \mathrm{~g} \mathrm{~kg}^{-1}$ for 45 to $90 \mathrm{~kg}$, and $2.80 \mathrm{~g} \mathrm{~kg}^{-1}$ for 90 to $135 \mathrm{~kg}$. On the other hand, the digestible phosphorus intake recommendations by the FEDNA tables (Blas et al., 2013) are $2.80 \mathrm{~g} \mathrm{~kg}^{-1}$ for 20 to $60 \mathrm{~kg}$ and $2.50 \mathrm{~g} \mathrm{~kg}^{-1}$ for 60 to $100 \mathrm{~kg}$.

Because phosphorus is an onerous ingredient in diets of pigs, we recommend the nutritional plan 3.192.88-2.68 $\mathrm{g} \mathrm{kg}^{-1}$ for better feed conversion, which represents the values recommended by the Brazilian tables (Rostagno et al., 2011) for the phases studied. O'Quinn et al. (1997) and Bünzen et al. (2012) did 
not find any effects on feed conversion for pigs in the growing phase. Similarly, Nieto et al. (2018) did not find any effects on feed conversion when evaluating nutritional plans of digestible phosphorus for barrows from 30 to $100 \mathrm{~kg}$.

Similar results to those observed for the carcass traits in the present study were found in different studies, such as those of Traylor et al. (2005), Arouca et al. (2010), Arouca et al. (2012), and Nieto et al. (2018), who evaluated pigs from growing to finishing phase fed diets with different available and digestible phosphorus levels.

It can be inferred that phosphorus levels did not affect manure production because they also did not alter the daily feed intake of the animals. The mean residue coefficient was $0.284 \mathrm{~kg}$ of manure per $\mathrm{kg}$ of body weight, which indicates that during the study period, the animals produced $0.284 \mathrm{~kg}$ of waste per $1.00 \mathrm{~kg}$ of body weight. Different values of residue coefficients were reported by Miranda et al. (2012), who found $0.230 \mathrm{~kg}$ of waste per $\mathrm{kg}$ of body weight for growing pigs and $0.470 \mathrm{~kg}$ of waste per $\mathrm{kg}$ of body weight for pigs from birth to slaughter. The purpose of assessing the residue coefficient in animal production is to determine whether the animal is efficiently using the feed it receives and turning it into a final product, i.e., swine transforming feed into meat. Values smaller than 1.0 indicate productive efficiency for the system.

The averages for TS and VS were 32.56 and $81.49 \%$, respectively. Values above $80 \%$ for VS indicate that a large amount of organic material is present in swine manure. If it does not receive the correct treatment, the manure could cause contamination of the environment. Miranda et al. (2012) found lower values for TS (23.80\%) and higher values for VS (85.9\%) for manure from pigs fed diets based on maize and sorghum.

The TS content refers to the material remaining after the removal of water from the waste by evaporation and the VS content, which is the part of TS lost in the form of volatile gases. Based on the VS content, it can be determined if the material is predominantly organic. Consequently, the correct treatment by biological or chemical methods can be determined. The VS content in swine manure varies according to the stage of animal body development (Souza et al., 2009).

The mean TP data (2.05\%) found in the present study is close to that observed by Miranda et al. (2012). Swine manure, rich in phosphorus and nitrogen, if deposited in the environment, can result in a number of problems. The major concern regarding nitrogen excretion in pig feces is related to the release of untreated manure into the environment, where it can be transformed into nitrates and leached into the water table (WHO, 2004). Phosphorus, when reaching water sources, promotes the growth and development of aquatic plants, increasing the competition between plants and aquatic animals for oxygen, in a process known as eutrophication (Moreira et al., 2010). The mean TN value in the manure was $3.34 \%$, which was lower than $3.97 \%$ for pigs fed a corn-based diet and $6.08 \%$ for pigs fed sorghumbased diets (Miranda et al., 2012).

Adequate phosphorus levels for growing and finishing pigs are those that meet the performance requirements with limited excretion into the environment. From our study, two results can be inferred. The first recommendation is a basal nutritional plan with $2.19-1.88-1.68 \mathrm{~g} \mathrm{~kg}^{-1}$ of digestible phosphorus, which corresponds to a daily intake of $4.26 \mathrm{~g}$. This diet did not compromise performance or the carcass traits, while from an environmental point of view, it resulted in a lower percentage of excreted TP and TN, thereby reducing waste pollution in the environment. The second recommended nutritional plan is 3.19-2.88-2.68 $\mathrm{g} \mathrm{kg}^{-1}$ of digestible phosphorus, corresponding to a daily intake of $6.62 \mathrm{~g}$, which presented a lower feed conversion.

\section{Conclusions}

The nutritional plans 3.19-2.88-2.68 and 3.69-3.38-3.18 $\mathrm{g} \mathrm{kg}^{-1}$ of digestible phosphorus, respectively, result in better feed conversion than the basal diet, the nutritional plan 2.19-1.88-1.68, for gilts from 30 to $100 \mathrm{~kg}$. This nutritional plan $2.19-1.88-1.68 \mathrm{~g} \mathrm{~kg}^{-1}$ of digestible phosphorus corresponds to levels of the basal diet and allows for a reduction in phosphorus excretion in the manure compared with other nutritional plans, except for nutritional plan 2.69-2.38-2.18 $\mathrm{g} \mathrm{kg}^{-1}$ of digestible phosphorus.

R. Bras. Zootec., 48:e20190116, 2019 


\section{Conflict of Interest}

The authors declare no conflict of interest.

\section{Author Contributions}

Conceptualization: K.C.N. Carvalho, C. Kiefer, K.M.R.S. Nascimento and T.M.B. Santos. Data curation: K.C.N. Carvalho, C. Kiefer, T.M.B. Santos, M.N. Bonin and S.A.S. Alencar. Formal analysis: K.C.N. Carvalho, C. Kiefer, M.N. Bonin and S.A.S. Alencar. Funding acquisition: C. Kiefer. Investigation: K.C.N. Carvalho, C. Kiefer, M.N. Bonin, S.A.S. Alencar, J.L. Silva and G.P. Rodrigues. Methodology: C. Kiefer, K.M.R.S. Nascimento, T.M.B. Santos, M.N. Bonin, J.L. Silva and G.P. Rodrigues. Project administration: C. Kiefer. Resources: C. Kiefer and M.N. Bonin. Software: M.N. Bonin. Supervision: C. Kiefer, K.M.R.S. Nascimento and T.M.B. Santos. Validation: K.C.N. Carvalho and C. Kiefer. Visualization: K.C.N. Carvalho, J.L. Silva and G.P. Rodrigues. Writing-original draft: K.C.N. Carvalho. Writing-review \& editing: C. Kiefer, K.M.R.S. Nascimento, T.M.B. Santos, M.N. Bonin, S.A.S. Alencar, J.L. Silva and G.P. Rodrigues.

\section{Acknowledgments}

The authors thank the Fundação de Apoio ao Desenvolvimento do Ensino, Ciência e Tecnologia do Estado de Mato Grosso do Sul (FUNDECT), Universidade Federal de Mato Grosso do Sul (UFMS), and Coordenação de Aperfeiçoamento de Pessoal de Nível Superior - Brasil (CAPES; Finance Code 001) for the financial support in the execution of the research project.

\section{References}

APHA.AWWA.WPCF. 2012. Standard methods for the examination of water and waste water. 21st ed. Washington, DC.

Arouca, C. L. C.; Fontes, D. O.; Silva, F. C. O.; Silva, M. A.; Almeida, F. R. C. L.; Corrêa, G. S. S.; Paula, E. and Haese, D. 2010. Níveis de fósforo disponível para suínos machos castrados dos 60 aos $95 \mathrm{~kg}$. Revista Brasileira de Zootecnia 39:2646-2655. https://doi.org/10.1590/S1516-35982010001200013

Arouca, C. L. C.; Silva, F. C. O.; Fontes, D. O.; Saraiva, A.; Donzele, J. L.; Silva, M. A. and Paula, E. 2012. Available phosphorus in diets for 15 to $30 \mathrm{~kg}$ pigs genetically selected for meat deposition. Revista Brasileira de Zootecnia 41:65-71. https://doi. org/10.1590/S1516-35982012000100010

Bünzen, S.; Rostagno, H. S.; Kiefer, C.; Teixeira, A. O. and Ribeiro Junior, V. 2012. Níveis de fósforo digestível para suínos em fase de crescimento. Revista Brasileira de Zootecnia 41:320-325. https://doi.org/10.1590/S1516-35982012000200013

Blas, C.; Gasa, J. and Mateos, G. G. 2013. Necesidades nutricionales para ganado porcino. Normas FEDNA. 2nd ed. Madrid. $114 \mathrm{p}$

Carvalho, N. L. and Zabot, V. 2012. Nitrogênio: nutriente ou poluente? Revista Eletrônica em Gestão, Educação e Tecnologia Ambiental 6:960-974. https://doi.org/10.5902/223611704671

Genova, J. L.; Pucci, L. E. and Sarubbi, J. 2015. Estratégias para diminuir o impacto ambiental da suinocultura. Revista Eletrônica Nutritime 12:3891-3902.

Gonzalo, E.; Létourneau-Montminy, M. P.; Narcy, A.; Bernier, J. F. and Pomar, C. 2018. Consequences of dietary calcium and phosphorus depletion and repletion feeding sequences on growth performance and body composition of growing pigs. Animal 12:1165-1173. https://doi.org/10.1017/S1751731117002567

Guidoni, A. L. 2000. Melhoria de processos para a tipificação e valorização de carcaças suínas no Brasil. p.221-234. In: Conferência Internacional Virtual sobre a Qualidade de Carne Suína. EMBRAPA - CNSA, Concórdia.

Hastad, C. W.; Dritz, S. S.; Tokach, M. D.; Goodband, R. D.; Nelssen, J. L.; DeRouchey, J. M.; Boyd, R. D. and Johnston, M. E. 2004. Phosphorus requirements of growing-finishing pigs reared in a commercial environment. Journal of Animal Science 82:2945-2952. https://doi.org/10.2527/2004.82102945x

Hendricks, W. H. and Moughan, P. J. 1993. Whole-body mineral composition of entire male and female pigs depositing protein at maximal rates. Livestock Production Science 33:161-170. https://doi.org/10.1016/0301-6226(93)90247-F

Lehninger, A. L.; Nelson, D. L. and Cox, M. M. 2005. Lehninger principles of biochemistry. 4th. ed. Freeman, W.H. New York, NY, USA. 
Miranda, A. P.; Lucas Júnior, J.; Thomaz, M. C.; Pereira, G. T. and Fukayama, E. H. 2012. Anaerobic biodigestion of pigs feces in the initial, growing and finishing stages fed with diets formulated with corn or sorghum. Engenharia Agrícola 32:47-59. https://doi.org/10.1590/S0100-69162012000100006

Moreira, J. A.; Vitti, D. M. S. S.; Patino, R. M.; Silva, T. S.; Bueno, I. C. and Berenchtein, B. 2010. Impacto ambiental provocado pelo P em dietas suplementadas com enzima fitase e proteína ideal para suínos em crescimento: estudo do fluxo do P no metabolismo animal. Arquivo Brasileiro de Medicina Veterinária e Zootecnia 62:1206-1215. https://doi.org/10.1590/ S0102-09352010000500025

NRC - National Research Council. 2012. Nutrient requirements of swine. 11th rev. ed. National Academies Press, Washington, D.C.

Nieto, V. M. O. S.; Kiefer, C.; Souza, K. M. R.; Gonçalves, L. M. P.; Bonin, M. N.; Santos, T. M. B.; Carvalho, K. C. N. and Santos, A. P. 2016. Digestible phosphorus levels for barrows from 50 to $80 \mathrm{~kg}$. Revista Brasileira de Zotecnia 45:242-249. https://doi.org/10.1590/S1806-92902016000500006

Nieto, V. M. O. S.; Kiefer, C.; Nascimento, K. M. R. S.; Gonçalves, L. M. P.; Marçal, D. A.; Abreu, R. C.; Santos, A. P. and Alencar S. A. S. 2018. Nutritional plans of digestible phophorus for growing-finishing barrows. Revista Brasileira de Zootecnia 47:e20170094. https://doi.org/10.1590/rbz4720170094

O'Quinn, P. R.; Knabe, D. A. and Gregg, E. J. 1997. Digestible phosphorus needs of terminal-cross growing-finishing pigs. Journal of Animal Science 75:1308-1318. https://doi.org/10.2527/1997.7551308x

Rostagno, H. S.; Albino, L. F. T.; Donzele, J. L.; Gomes, P. C.; Oliveira, R. F. M.; Lopes, D. C.; Ferreira, A. S.; Barreto, S. L. T. and Euclides, R. F. 2011. Tabelas brasileiras para aves e suínos. 3.ed. UFV-DZO, Viçosa, MG.

Rostagno, H. S.; Albino, L. F. T.; Hannas, M. I.; Donzele, J. L.; Sakomura, N. K.; Perazzo, F. G.; Saraiva, A.; Teixeira, M. L.; Rodrigues, P. B.; Oliveira, R. F.; Barreto, S. L. T. and Brito, C. 0. 2017. Tabelas brasileiras para aves e suínos. 4.ed. UFV-DZO, Viçosa- MG.

Saraiva, A.; Donzele, J. L.; Oliveira, R. F. M.; Abreu, M. L. T.; Silva, F. C. O. and Haese, D. 2009. Níveis de fósforo disponível em rações para suínos de alto potencial genético para deposição de carne dos 30 aos 60 kg. Revista Brasileira de Zootecnia 38:1279-1285. https://doi.org/10.1590/S1516-35982009000700017

Silva, D. J. and Queiroz, A. C. 2002. Análise de alimentos: métodos químicos e biológicos. 3.ed. Imprensa Universitária da UFV, Viçosa, MG.

Souza, C. F.; Carvalho, C. C. S.; Campos, J. A.; Matos, A. T. and Ferreira, W. P. M. 2009. Caracterização de dejetos de suínos em fase de terminação. Revista Ceres 56:128-133.

Stahly, T. S.; Lutz, T. R. and Clayton, R. D. 2000. Dietary available phosphorus needs of high lean pigs fed from 9 to $119 \mathrm{~kg}$ body weight. Swine Research Report. Paper 4

Traylor, S. L.; Cromwell, G. L. and Lindemann, M. D. 2005. Bioavailability of phosphorus in meat and bone meal for swine. Journal of Animal Science 83:1054-1061. https://doi.org/10.2527/2005.8351054x

WHO - World Health Organization. 2004. Rolling revision of the WHO guidelines for drinking-water quality. Draft for review and comments. Nitrates and nitrites in drinking water. WHO, Genebra. 